\title{
Measuring and assessing management of forested landscapes
}

\author{
by W. Wardoyo ${ }^{1}$ and G. A. Jordan ${ }^{1}$
}

Forest management assessment is poorly understood and rarely undertaken in practice. In current practice, forest responses to management interventions are not typically monitored and evaluated. Consequently, any sense of objective achievement is lacking. Assessment of forest response is necessary, however, to ensure that forest management efficiently and effectively moves a forest toward a desired objective, by detecting deviation and adjusting management strategy accordingly.

This paper proposes a framework for forest management assessment centred on the landscape, or ecosystem, management model. The framework identifies spatial forest structure, i.e. the array, amounts and geographical arrangement of forest conditions, as a basis for setting forest objectives, establishing spatial management strategies, and periodically measuring and assessing forest responses. Periodic measurement of spatial forest structure will be a significant challenge in implementing the assessment framework proposed. The potential of digital satellite imagery and GIS technologies is examined, using a Landsat TM image and the $\mathrm{Arc} / \mathrm{Info}^{\mathrm{TM}}$ and Easi/Pace ${ }^{\mathrm{TM}}$ software systems, and found wanting.

Key words: forest management, landscape, GIS, satellite imagery
L'évaluation de l'aménagement forestier constitue une notion peu comprise et en pratique rarement appliquée. Dans la pratique courante, les réponses des forêts aux interventions d'aménagement ne sont pas habituellement surveillées et évaluées. En conséquence, toute notion de réalisation objective demeure absente. L'évaluation de la réponse des forêts est nécessaire, toutefois, pour s'assurer que l'aménagement forestier permet efficacement et effectivement à une forêt de se diriger vers l'objectif recherché, en détectant les déviations et en ajustant la stratégie d'aménagement en conséquence.

Cet article propose un cadre de référence de l'évaluation de l'aménagement forestier centré sur un modèle d'aménagement du paysage, ou de l'écosystème. Le cadre identifie la structure spatiale de la forêt, c'est-à-dire, l'étendue, les quantités et la disposition géographique des éléments forestiers, en tant que base pour l'établissement d'objectifs forestiers, pour l'élaboration de stratégies d'aménagement spatial, et pour la mesure et l'évaluation périodique des réponses de la forêt. La mesure périodique de la structure spatiale de la forêt constituera une défi important à l'implantation du cadre d'évaluation proposé. Le potentiel de l'imagerie satellite digitale ainsi que les technologies GIS est étudié en fonction des images Landsat TM et des systèmes logiciels $\mathrm{Arc} / \mathrm{Info}^{\mathrm{TM}}$ et Easi/Pace ${ }^{\mathrm{TM}}$, et semble être absent.

Mots clés: aménagement forestier, paysage, technologies GIS

\section{Introduction}

Forest management assessment is poorly understood and rarely found in practice. Typical factors examined in contemporary evaluation of forest management performance are related to administrative accomplishment, conformity of a proposed management schedule and its implementation, and stand responses to intervention. For example, performance assessment commonly focuses on the quality of resource information used in preparing a management plan, confirmation that harvest volumes actually came from blocks identified in the plan, and stocking of cutovers. This type of evaluation does not examine the condition of a forest resulting from management interventions relative to target objectives. In fact, in current practice forest objectives are rarely stated.

Assessment should be, however, an integral part of forest management. Forest management supposedly seeks to control the complex and uncertain dynamics of forest change in a desired direction. In the absence of periodic assessment, the effects of management interventions on forest change will be unknown and, therefore, any sense of objective achievement lacking. Assessment, on the other hand, would allow management to efficiently and effectively move a forest toward a desired objective, by detecting deviation and adjusting intervention strategies accordingly.

Garnet Strong Laboratory, Faculty of Forestry and Environmental Management, University of New Brunswick, Fredericton, New Brunswick, Canada E3B 6C2.
This paper proposes a framework for forest management assessment, using the forest landscape, or ecosystem, model. GIS and digital image analysis techniques are examined as a means to meet the framework's need to periodically gather measurements of forest landscape conditions in an efficient and effective manner.

\section{Forest Management Decision-making}

In current practice, forest management involves a "linear" decision-making process (Fig. 1). Typically, a set of harvest and silviculture interventions that provide an acceptable level of sustainable wood supply for the working portion of a forest are first identified. Next the interventions are gradually implemented, subject to a host of operating regulations; such as maximum harvest opening size, for example. A forest response eventually emerges. In this linear approach, forest feedback control does not exist, since there is no stated forest objective as a basis for evaluating forest response to intervention. Probably the harvest level objective will be achieved and the regulations will be followed. The forest that emerges, however, will not be measurable against a target. Management has not focused on achieving a forest condition - a specific age class structure, for example — as a basis for sustaining timber and non-timber flows. In such a case, forest management does not exist.

Management of complex systems, like forests, require a "circular" decision-making approach that incorporates a feedback 
Fig. 1. Forest management as a linear decision-making process.

loop (Senge 1990). A feedback mechanism is the most important feature of any control system because feedback operates by detecting deviation from the planned direction, and directs the system back toward the designated objective (Baskerville 1984). A feedback mechanism was identified clearly by the Canadian Standards Association (CSA) in developing its framework for sustainable forest management certification (Anonymous 1995). The document states: "Feedback loops should be identified and used for improving the sustainable forest management system by incorporating knowledge gained from ongoing assessments and reviews".

By incorporating a feedback loop into the forest management process, a circular approach would allow management effectiveness to be determined periodically and adjustments made as necessary (Fig. 2). For example, if forest managers could express objectives in terms of forest conditions, a gap between current state and desired state would be observed. This gap would motivate interventions aimed at bringing the existing forest to the desired state through time. In some forests, however, a gap may not exist. For example, if the forest objective were a natural forest state, large portions of the Boreal Forest would satisfy this today. In this case, some authors suggest that management interventions that mimic natural disturbances would be appropriate to maintain the natural forest state (Harris 1984; Oliver 1992). Regardless, on-ground implementation of interventions will gradually generate a forest response. Examination of the new forest condition would reveal its position relative to the objective, natural or otherwise. This feedback would permit a reassessment of the gap between current forest state and desired forest state. Depending upon the size of the gap, forest managers would be stimulated to enhance management effectiveness by changing the management strategy or by modifying the forest objective.

\section{Forest Landscape Management}

Current forest management focus on resource-centred objectives, as opposed to forest-centred ones, precludes an effective circular decision making process. However, forest landscape or ecosystem management, while in the early stages of evolution and development, suggests that objectives should indeed focus on the forest. Specifically, landscape management proponents suggest that "spatial forest structure", i.e. the array, amounts and geographical arrangement of forest conditions across a forested landscape, be the basis of establishing forest management objectives (Franklin 1990; Salwasser 1990; Swanson and Franklin 1992; O'Hara et al. 1994; Baskent 1995). There seems to be broad agreement that spatial forest structure plays an important role in determining the availability of forest values like timber, as well as determining ecological well-being like biodiversity. For example,

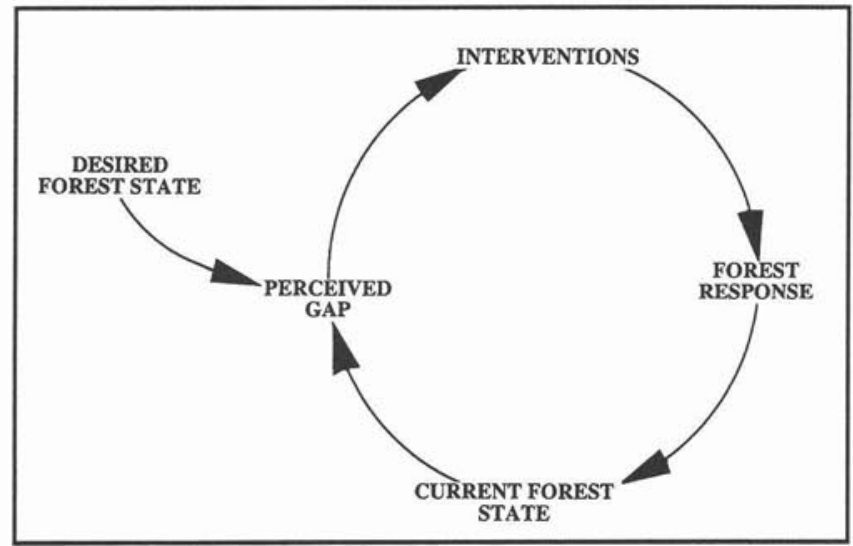

Fig. 2. Forest management as a circular decision making process.

Jordan et al. (1995) indicated that spatial forest structure (aggregated vs fragmented) influences the availability of operable timber for harvest. In a similar vein, Harris (1984) noted that fragmented forests may contribute to the loss of some wildlife species, while Oliver (1992) suggested that spatial forest structure is important in the larger issue of maintaining overall forest biodiversity.

In forest landscape management, then, spatial forest structure will serve as a "common currency" for establishing management objectives for multiple values, and assessing forest response to management.

\section{Measuring Spatial Forest Structure}

Traditionally, measuring forest structure has been limited to aspatial "descriptive attributes" that provide areas or frequencies of occurrences of forest conditions. Forest ageclass distribution is a typical example. Spatial forest structure, however, involves not only the array and amounts of a forest's conditions, but their geographical arrangement as well. With this perspective, "patches" of uniform condition emerge across a forest, but vary depending upon the forest value, or patch type, of interest. Patches are easily delineated on forest covertype maps or satellite images, using GIS and image analysis software. For example, timber patches would emerge as individual stands, or clusters of adjacent stands of operable age classes on a covertype map (Fig. 3). From a biodiversity perspective, however, each individual stand would represent a unique patch of distinct age class or species composition. Across a satellite image patches would appear as clusters of individual pixels of the same value, i.e. patch type.

Measuring spatial forest structure, for purposes of establishing forest objectives or monitoring forest response to management, would involve a host of new "locational attributes". Locational attributes of forest landscapes would characterize the geographical arrangement of forest conditions and might, for a given patch 


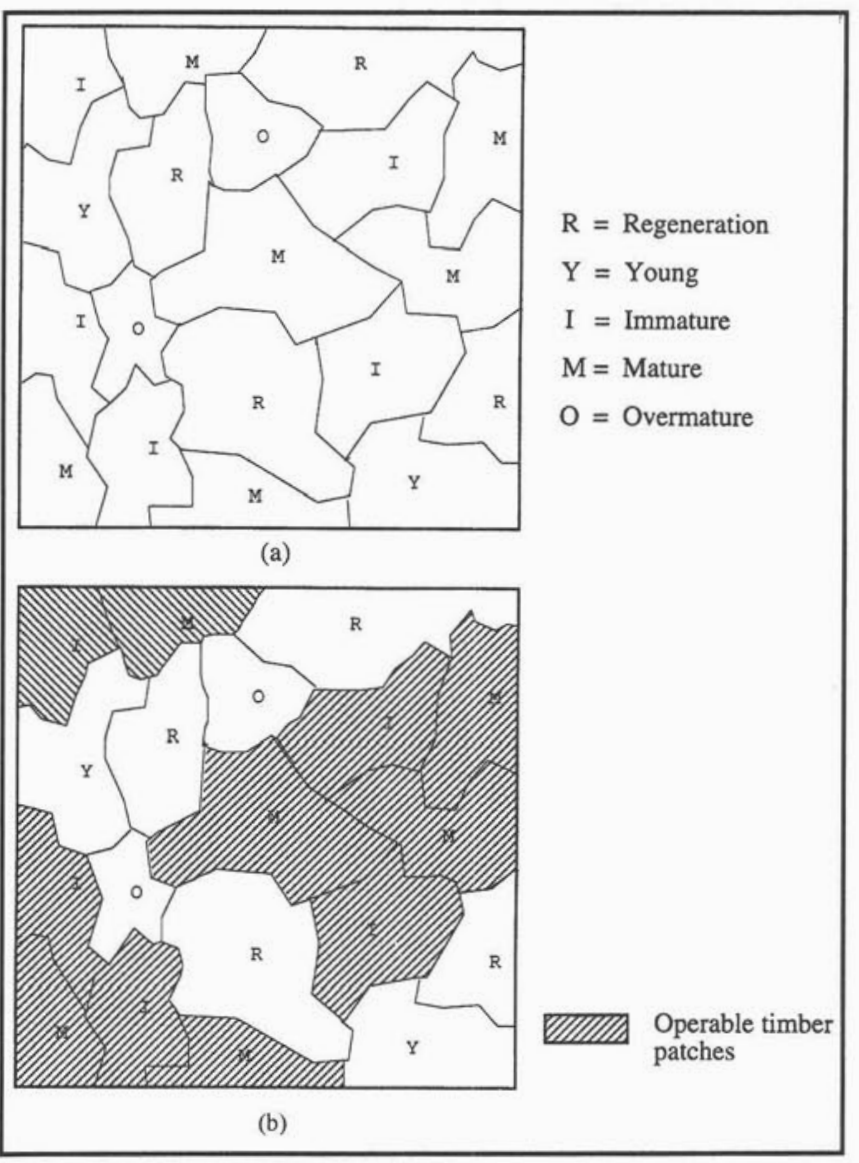

Fig. 3. Operable timber (I and $M$ ) patches (b) derived from a map of stand age classes (a).

type or types, include measures of fragmentation, complexity, dispersion, interspersion, isolation or connectivity. Dozens of measures of landscape patterns and structure have been developed (Turner 1989; McGarigal and Marks 1994; Baskent 1995). McGarigal and Marks (1994) classified landscape measures into three groups of metrics: patch, class and landscape. In similar fashion, Baskent (1995) organised spatial structure measurements into patch and landscape categories.

Landscape measurements would allow forest objectives for multiple values to be set and, ultimately, management performance to be monitored and assessed. For example, spatial autocorrelation characterizes the fragmentation or patchiness of specified conditions across a forested landscape (Cliff and Ord 1981). It is an important indicator of timber supply economics (Baskent 1995), as well as biodiversity (Legendre 1993), and ranges from -1 to +1 . A positive spatial autocorrelation indicates occurrence of clusters, or patches, of like conditions across a forest landscape. A negative spatial autocorrelation indicates a lack of clusters, or patches, and a "fragmented" forest state. A value near zero indicates a random distribution of patch type conditions. Fractal dimension (D), on the other hand, is often used to measure patch shape complexity (Mandelbrot 1983). It is usually applied across entire forested landscapes (Burrough 1986; McGarigal and Marks 1994). In this paper, it is calculated as the mean perimeter and area ratio of all patches across a landscape. It would approach one in forests dominated by simple patch shapes similar to rectangles, squares or circles. In landscapes composed of patches of more complex and irregular shapes, fractal dimension approaches two. Shape complexity is an important indicator for both timber harvest economics and biodiversity. For example, an irregularly-shaped harvest block requires more operating road construction than a more compact, regularly-shaped one (Baskent 1995). A forest whose operable timber was characterized by a fractal dimension approaching two would not be particularly desirable from a harvesting economics point of view. This same forest would not be desirable form a species richness point of view either, since it has been observed that species diversity decreases progressively towards the tips of lobes protruding from large patches (Forman and Godron 1986). Another measure of spatial forest structure is core area. Core area is the "usable" interior area within patches. Most species of forest birds depend upon the availability of large patches with large core area (Whitcomb et al. 1981). Total core area across a forest landscape is, therefore, an important index of bird populations.

Initial measurement and periodic monitoring of spatial forest structure change as a forest responds to management would be impractical using conventional inventory techniques. Satellite imagery, on the other hand, is potentially an efficient and effective alternative. The data are collected at frequent intervals; they cover large areas and are in digital form. Further, GIS and digital image analysis software, needed to process the satellite data to characterize spatial forest structure in terms like those mentioned previously, are well developed (McGarigal and Marks 1994; Baskent 1995). Therefore, as Lachowski et al. (1994) stated, remotely sensed data and GIS have potential to play a key role in forest ecosystem management. The section that follows uses $\mathrm{Arc} / \mathrm{Info}^{\mathrm{TM}}$ and Easi/Pace ${ }^{\mathrm{TM}}$ software to test the effectiveness of Landsat TM imagery in measuring spatial forest structure for a portion of New Brunswick forest.

\section{A New Brunswick Example}

Both timber and biodiversity have significant social and economical values for the province of New Brunswick. As such, their continued sustainable development are common goals in forest management. How these goals are translated into management objectives has varied over the past 20 years; but, if a forest landscape management approach were used in New Brunswick today, forest objectives would involve not only the area distribution of age classes across the forest, but their geographical distribution as well. Timber harvest would be limited by the future availability of operable age classes whose geographical distribution permitted harvest blocks of economical size and configuration to be formed (Jordan et al. 1995). Likewise, maintenance of biodiversity will require the presence of a wide spectrum of forest patches in terms of species compositions, age classes, sizes, shapes and spatial arrangements (Oliver 1992; Lippke and Oliver 1993). This wide spectrum of patches would ensure the widest array of forest plant and animal diversity (Oliver 1992).

Ideally, then, any portion of the New Brunswick forest managed for both a sustainable timber harvest and biodiversity would have requisite forest conditions present continuously. For example, management objectives might be the achievement of: (i) a balanced area distribution of the full range of forest age classes $(0$ to $120+)$ to ensure availability of operable timber for harvest and to also maintain biodiversity potential; 


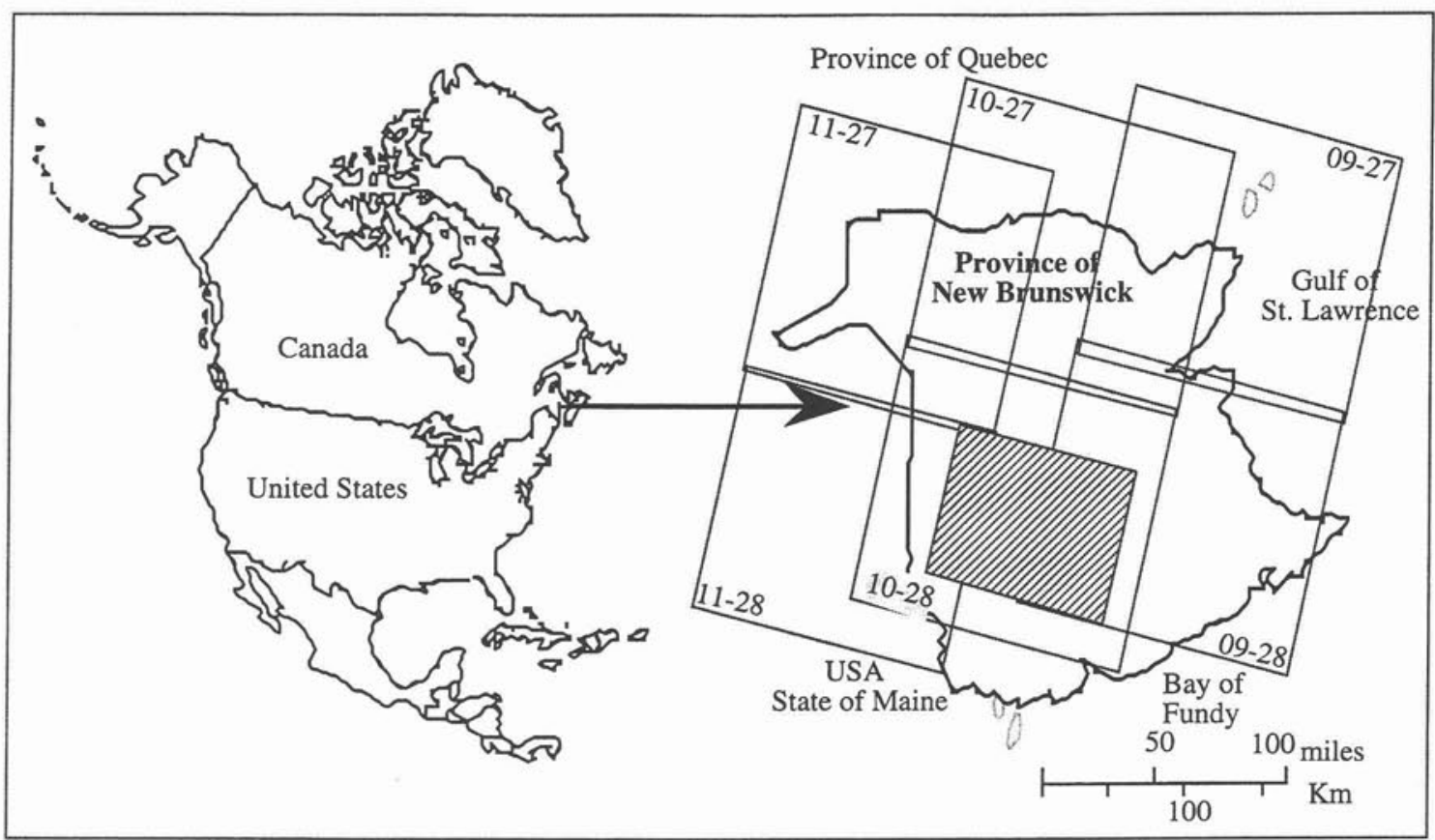

Fig. 4. The 310,000 ha study area shaded on the Landsat TM scene index.

\begin{tabular}{ll}
\hline Table 1. Species types used in the case study \\
\hline Species type & Description \\
\hline Hardwood (HW) & $\begin{array}{l}\text { Hardwood volume is equal to or greater } \\
\text { than } 75 \%\end{array}$ \\
Softwood (SW) & $\begin{array}{l}\text { Softwood volume is equal to or greater } \\
\text { than } 75 \%\end{array}$ \\
Hardwood/softwood (HS) & $\begin{array}{l}\text { Volume of hardwood is equal to or } \\
\text { greater than } 50 \%, \text { but less than } 75 \%, \text { and } \\
\text { softwood volume is equal to or greater } \\
\text { than } 50 \%\end{array}$ \\
Softwood/hardwood (SH) & $\begin{array}{l}\text { Volume of softwood is equal to or } \\
\text { greater than } 50 \%, \text { but less than } 75 \%, \text { and } \\
\text { hardwood volume is equal to or greater } \\
\text { than } 50 \%\end{array}$ \\
\hline
\end{tabular}

(ii) a balanced area distribution of operable patch sizes (across the array of age classes and species types) to maintain economical timber harvest potential while maintaining biodiversity, (iii) a spatial autocorrelation greater than 0.50 for the operable timber patch type (all species types in age classes 60 to 120) to ensure presence of economical timber harvest blocks, and a spatial autocorrelation greater than 0.50 for biodiversity patch types (all species types and age classes ) to ensure connectivity among patches and maintenance of biological diversity, and; (iv) a relatively high fractal dimension of 1.50 for both operable timber and biodiversity patch types to ensure the availability of regular shaped, economical harvest blocks while also maintaining a range of patch shapes (regular-irregular-complex) for biodiversity.

As already noted (Fig. 2), documenting current state of a forest's spatial structure is the first step in designing forest landscape management. Comparison of current and desired forest states reveals gaps that provide a basis for designing a forest

\begin{tabular}{lcc}
\hline \multicolumn{3}{l}{ Table 2. The accuracy of species type and age class classification } \\
\hline & Species type & Age class \\
\hline Hardwood (HW) & $85 \%$ & $46 \%$ \\
Softwood (SW) & $74 \%$ & $57 \%$ \\
Hardwood/softwood (HS) & $80 \%$ & $53 \%$ \\
Softwood/hardwood (SH) & $64 \%$ & $55 \%$ \\
Overall forest & $79 \%$ & $52 \%$ \\
\hline
\end{tabular}

management strategy. Periodic measurement of subsequent forest response would be used to assess the success of the strategy and guide design changes as necessary. In sections that follow, a Landsat TM image of a portion of New Brunswick forest is processed with Easi/Pace ${ }^{\mathrm{TM}}$ and $\mathrm{Arc} / \mathrm{Info}^{\mathrm{TM}}$ software to document its spatial structure relative to the aforementioned hypothetical timber and biodiversity objectives. This serves as a basis for determining the effectiveness of Landsat TM imagery in measuring spatial forest structure. As noted earlier, an efficient and effective means of measuring spatial forest structure will be needed to successfully implement the forest management assessment framework described in this paper.

\section{Landsat TM Image Classification}

A 310,000 ha Landsat image - path 10, row 28 consisting of seven bands, taken on September 2,1993 — was acquired and processed (Fig. 4). Measurement involved using Easi/Pace ${ }^{\mathrm{TM}}$ to classify the forest landscape by species types and age classes. Four broad species types were used - softwood (SW), hardwood (HW), hardwood/softwood (HS), and softwood/hardwood (SH) (Table 1), while five age classes were identified - Regenerating ( $0-30)$, Young (30-60), Immature (60-90), Mature (90-120), and Overmature (120+). 


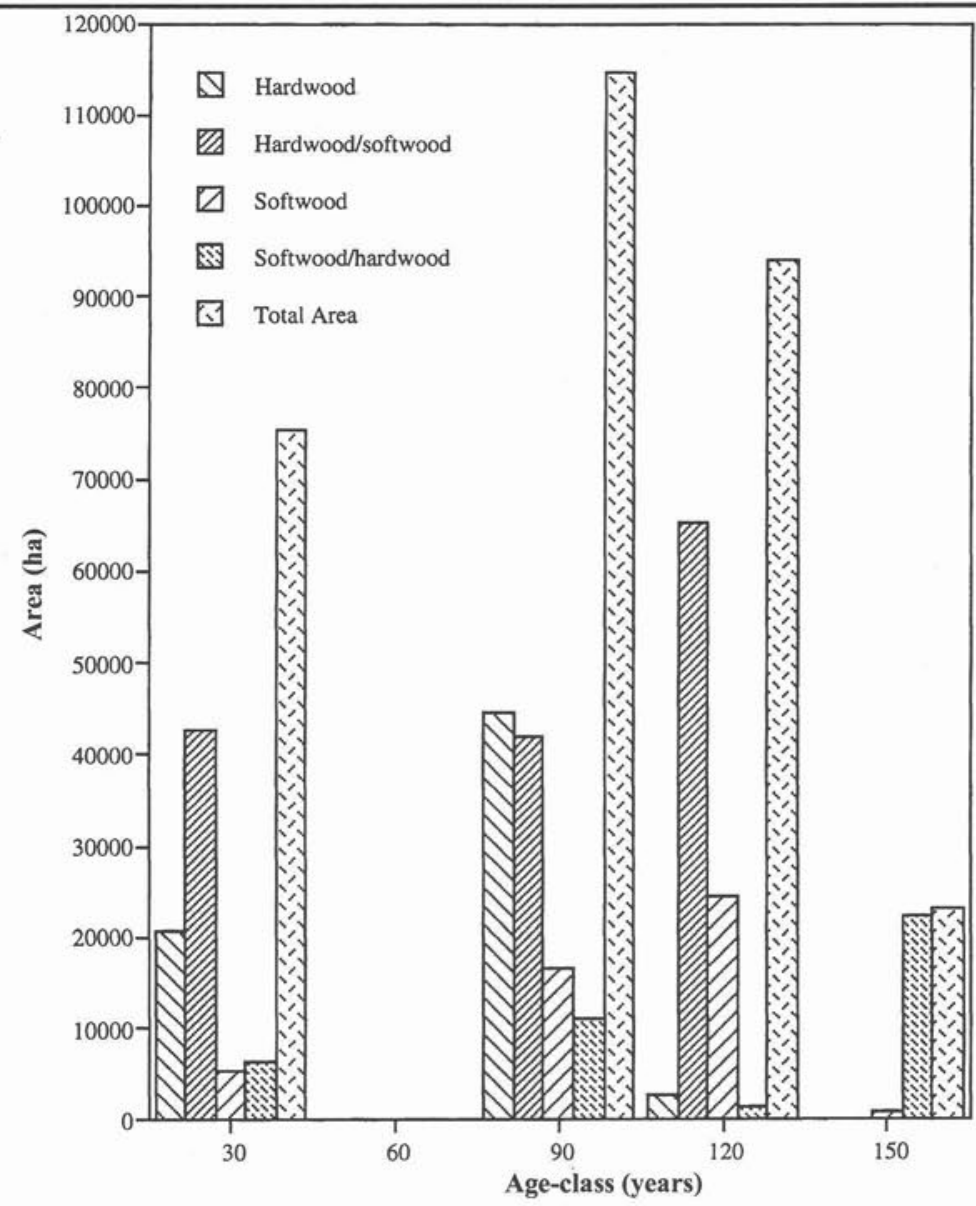

Fig. 5. Age class distribution by species type derived from the Landsat TM image.

Species type and age class classifications were aided by GIS map information provided by the Timber Management Branch (TMB) of the New Brunswick Department of Natural Resources and Energy (DNRE). These consisted of forest polygon (stands), line (roads and streams), and point (permanent sample plots - PSP) Arc/Info ${ }^{\mathrm{TM}}$ coverages. The polygon and line coverages permitted registration of the Landsat image ( $\mathrm{rms}$ $=0.3 \mathrm{~m}$ ), while the PSP point coverage data provided species type and age class values used in determining training areas in Easi/Pace ${ }^{\mathrm{TM}}$. An unsupervised classification was performed to identify species types and age classes. Then, a supervised classification (maximum likelihood) scheme was used to classify the four species types and five age classes. The accuracy of classification based upon PSP data available in the study area was $79 \%$ for species types, and $52 \%$ for age classes (Table 2).

\section{Landscape Measurements}

Using the features of both Easi/Pace ${ }^{\mathrm{TM}}$ and GRID-Arc/Info ${ }^{\mathrm{TM}}$, spatial forest structure measurements were derived from the classified Landsat image in accordance with the originally stated forest landscape objectives. First, Easi/Pace ${ }^{\mathrm{TM}}$ allowed operable timber and biodiversity patch types to be identified and mapped. Image pixels classified with ages between 60 and 120 years (immature to mature) for each species type were con- sidered operable timber patch type. All pixels classified as regeneration, young, immature, mature or overmature for each species type were treated as biodiversity patch type. Next, Easi/Pace ${ }^{\mathrm{MM}}$ was used to determine spatial autocorrelation values for the two patch type images. This was accomplished using a program written in Pace Fortran for Easi/Pace ${ }^{\mathrm{TM}}$. Moran's I coefficient was used in the calculation as it is less affected by the distribution of the sample data (Cliff and Ord 1981) than other spatial autocorrelation calculations (e.g., Geary's c coefficient, joint-count statistics). Moran's I is calculated as:

$$
I=\frac{n \sum_{i} \sum_{j} W_{i j}\left(x_{i}-\bar{x}\right)\left(x_{j}-\bar{x}\right)}{A \sum_{i}\left(x_{i}-\bar{x}\right)^{2}}
$$

where $n$ is the number of grid cells on the image; $W_{\mathrm{ij}}$ is the spatial relationship between the $i$ th and $j$ th cells: 1 for adjacent cells and 0 otherwise; $x_{\mathrm{i}}$ is a cell value that forms a patch type; $\bar{x}$ is the average of all cell values; $A=\Sigma_{\mathrm{i}} \sum_{\mathrm{j}} W_{\mathrm{ij}}$ is the total number of neighbouring cells. Finally, an age class distribution (Fig. 5) was computed and, once the patch type image was converted to a single variable file and exported to GRID-Arc/Info ${ }^{\mathrm{TM}}$, patch area distributions (Fig. 6) and mean patch fractal dimension (MPFD) were calculated. Since data in raster format cause a bias in perimeter determination, a factor of 0.25 was used to 


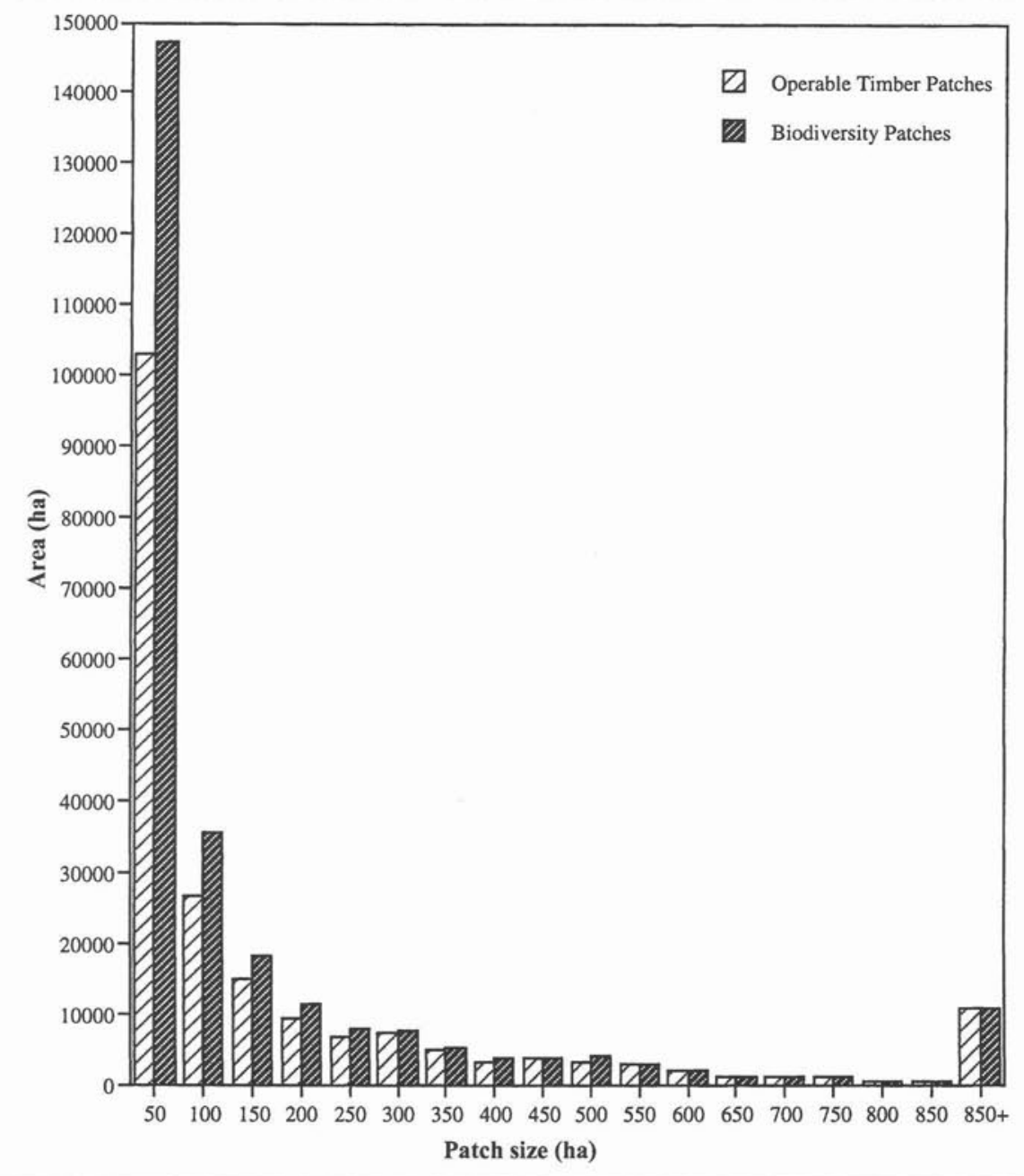

Fig. 6. Area distribution of operable timber and biodiversity patch sizes.

adjust the formula (McGarigal and Marks 1994). The adjusted formula is:

$$
M P F D=\frac{\sum_{j=1}^{n}\left(\frac{2 \ln \left(0.25 p_{i j}\right)}{\ln a_{i j}}\right)}{n_{i}}
$$

where $a_{\mathrm{ij}}$ is the area of patch $_{\mathrm{ij}}, p_{\mathrm{ij}}$ is the perimeter of patch ${ }_{\mathrm{ij}}$, and $n_{\mathrm{i}}$ is the number of patches across the landscape.

\section{Assessment}

Examination of spatial forest structure measurements indicates that some gaps exist between originally stated forest objectives for timber harvest and biodiversity, and actual forest state. Immature and mature forest conditions, important for both timber harvest and biodiversity, exist, but the gap between regeneration $(0-30)$ and immature (60-90) age classes is unsatisfactory for both timber harvest and maintenance of biodiversity (Fig. 6). In addition, the area distribution of the five species types is imbalanced and dominated by immature and mature development stages of hardwood-softwood species types.
The patch size distribution (Fig. 6) shows that patches of less than 50 ha are the majority for both operable timber and biodiversity patch types - $49.7 \%$ for operable timber, $54.7 \%$ for biodiversity. In each case, not more than $5 \%$ of patches are larger than 850 ha ( $5 \%$ operable timber; $4 \%$ biodiversity). Thus the study area falls short of the objective to maintain a balanced area distribution of species types and age classes, and their patch sizes.

All species types have positive spatial autocorrelations. Spatial autocorrelations for each species type were $0.37,0.29,0.50$, and 0.27 for HW, SW, HS, SH of operable timber; and 0.37, $0.28,0.46$, and 0.32 for HW, SW, HS, SH of biodiversity (Table 3). Overall spatial autocorrelation was 0.31 for operable timber patch type, and 0.23 for biodiversity patch type; it is less than the desired spatial autocorrelation 0.50 . These confirm that the desired patchiness for operable timber and biodiversity does not exist across the study area.

Fractal dimension measurements indicated that most patches have regular shapes. Average fractal dimension was 1.04, $1.06,1.06$, and 1.04 for $\mathrm{HW}, \mathrm{SW}, \mathrm{HS}, \mathrm{SH}$ of operable timber, whereas fractal dimension for biodiversity was $1.05,1.06,1.05$, and 1.04 (Table 3 ). The average fractal dimension over the land- 
Table 3. Spatial autocorrelation and mean patch fractal dimension measurements for operable timber and biodiversity

\begin{tabular}{lccccc}
\hline & \multicolumn{2}{c}{ Spatial autocorrelation } & & \multicolumn{2}{c}{ Fractal dimension } \\
\cline { 2 - 3 } \cline { 5 - 6 } & $\begin{array}{c}\text { Operable } \\
\text { timber }\end{array}$ & Biodiversity & & $\begin{array}{c}\text { Operable } \\
\text { timber }\end{array}$ & Biodiversity \\
\hline Hardwood (HW) & 0.37 & 0.28 & & 1.04 & 1.05 \\
$\begin{array}{l}\text { Softwood (SW) } \\
\text { Hardwood/ }\end{array}$ & 0.50 & 0.46 & & 1.06 & 1.05 \\
$\begin{array}{l}\text { softwood (HS) } \\
\text { Softwood/ }\end{array}$ & 0.29 & 0.28 & & 1.06 & 1.06 \\
hardwood (SH) & 0.27 & 0.46 & & 1.04 & 1.06 \\
Overall forest & 0.31 & 0.23 & 1.05 & 1.05 \\
\hline
\end{tabular}

scape was 1.05 for both operable timber and biodiversity. These are acceptable for economical timber harvest, but fall short of the target 1.50 needed for biodiversity maintenance.

Measurement and characterization of actual forest condition from Landsat TM image processing has shown that some obvious deviations exist in the study forest relative to stated objectives for timber harvest and biodiversity. These deviations would provide feedback to management and provide a basis for designing a management strategy. Similar processes would be used to periodically monitor forest landscape change as the management strategy was implemented, and the feedback provided used to adjust the management strategy accordingly.

\section{Conclusions}

Implementing the forest landscape management assessment framework proposed in this paper will require: (i) a much greater refinement of the forest landscape management model, including much deeper understanding of the implications of spatial forest structure for timber and non-timber values; (ii) an array of new spatial management strategies; and (iii) the ability to periodically measure spatial forest structure change in an efficient and effective manner. None of these is trivial. This paper has investigated the use of Landsat TM imagery as a solution for the last point only. Unfortunately, large errors in accuracy of classification of broad forest species types and age classes were found in the New Brunswick case study. These will limit the use of Landsat TM imagery in forest landscape management assessment today. Although the $30-\mathrm{m}$ spatial resolution of Landsat TM is better than that of its predecessor (Landsat MSS), a single pixel may contain a mixture of several species types or ages. Better spatial resolution e.g., SPOT or MEIS, would provide better results of classification of species types and age classes than achieved in this study. Further, Landsat TM only has seven bands. This also limits separation of species types and age classes. The use of narrower spectral bands would provide better separation of the image data. Airborne data such as that provided by AVIRIS, consisting of 224 bands, is an example. When the next generation in satellite technology appears, improved spatial and spectral resolutions may make practical forest landscape monitoring and management assessment possible.

\section{Acknowledgements}

This research was funded by an NSERC Collaborative Research and Development grant involving eight industrial partner s - Corner Brook Pulp \& Paper Ltd., Fraser Inc., J.D. Irving
Ltd., Juniper Lumber Co. Ltd., Stone Consolidated. (Kenora), Repap NB, and St. Anne Pulp Co. Ltd., and the New Brunswick Department of Natural Resources and Energy. PCI (Canada) provided software support. Description of this, and other research projects at the Garnet Strong Laboratory can be found at http://www.strong.unb.ca/

The thorough reviews of two anonymous referees are greatly appreciated.

\section{References}

Anonymous. 1995. A sustainable forest management system: overview document (Draft). Canadian Standards Association. Ottawa, ON.

Baskent, E.Z. 1995. Forest landscape management: concept and practice. Unpublished $\mathrm{PhD}$ Thesis. University of New Brunswick, Fredericton, NB. $\mathrm{x}+132 \mathrm{p}$.

Baskerville, G.L. 1984. Adaptive management: wood availability and habitat availability, Forestry Chronicle 70: 171-175.

Burrough, P.A. 1986. Principles of geographical information systems for land resources assessment. Clarendon Press, Oxford, UK. $193 \mathrm{p}$.

Cliff, A.D. and J.K. Ord. 1981. Spatial processes: models and applications. Pion Ltd. London, UK. 266 p.

Forman, R.T.T. and M. Godron. 1986. Landscape ecology. John and Sons, New York, NY.

Franklin, J. F. 1990. "New Forestry" and the old growth forests of northwestern North America. Northwest Environmental Journal 6: 445-461.

Harris, L.D. 1984. The fragmented forest: Island biographic theory and the preservation of biotic diversity. University of Chicago Press, Chicago, IL. 211 p.

Jordan, G.A., E.Z. Baskent and G.A. Whittaker. 1995. Spatial forest modelling and landscape management. Pp. 473-479 In: Proceedings of the ninth annual symposium on geographic information systems: the next step. GIS World Inc., Vancouver, BC. p.

Lachowski, H.M., T. Wirth, P. Maus and P. Avers. 1994. Remote sensing and GIS: Their role in ecosystem management. Journal of Forestry 92(8): $39-40$.

Legendre, P. 1993. Spatial autocorrelation: Trouble or new paradigm? Ecology 74(6): 1659-1673.

Lippke, B. and C.D. Oliver. 1993. Managing for multiple values. Journal of Forestry. 91(12): 14-18.

McGarigal, K. and B.J. Marks. 1994. FRAGSTATS: Spatial pattern analysis program for quantifying landscape structure. Forest Science Department, Oregon State University, Corvalis, OR. 67 p.

Mandelbrot, B. B. 1983. Geometry of nature. W.H. Freeman \& Co., San Fransisco, CA. 468 p.

O'Hara, K.L., R.S. Seymour, S.D. Tesch and J.M. Guldin. 1994. Silviculture and our changing profession: leadership for shifting paradigms. Journal of Forestry 92(1): 8-13.

Oliver, C.D. 1992. Achieving and maintaining biodiversity and economic productivity. Journal of Forestry 90(9): 20-25.

Salwasser, H. 1990. Gaining perspective: Forestry for the future. Journal of Forestry 88(11): 33-38.

Senge, P.M. 1990. The fifth discipline: the art and practice of the learning organization. Doubleday, New York, NY. viii +424 p.

Swanson, F. J. and J. F. Franklin. 1992. New forestry principles from ecosystem analysis of Pacific Northwest forests. Ecological Applications 2(3): 262-274.

Turner, M.G. 1989. Landscape ecology: the effect of pattern on process. Annu. Rev. Ecol. Syst. 20: 171-197.

Whitcomb, R.F., C.S. Robbins, J.F. Lynch, B.L. Whitecomb, M.K. Klimkiewick and D. Bystrak. 1981. Effects of forest fragmentation on avifauna of the eastern deciduous forest. Pp. 125-205 In: Forest island dynamics in man-dominated landscapes. B. Burgess and D. Sharpe, Eds. Springer-Verlag, New York Inc., New York, NY. 